\title{
Entomopathogenic activity of bacterial and viral strains from the bioresource collection "State Collection of Entomoacariphages and Microorganisms"
}

\author{
Elena Yu. Bondarchuk, Alexandra A. Tsygichko*, Natalia S. Tomashevich, and Anzhela M. \\ Asaturova
}

Federal Research Center of Biological Plant Protection, Krasnodar, Russia

\begin{abstract}
As a result of a series of experiments to study the entomopathogenic activity of bacteria and viruses from the "State Collection of Entomoacariphages and Microorganisms", it was revealed that the large wax moth Galleria mellonella $\mathrm{L}$. it is sensitive to new strains of bacteria and viruses. In the future, the strains can be used in the subsequent stages of screening of microorganisms that are promising as agents of biological pest control. The maximum biological efficacy on the fifth day against the tested insect was observed when using bacterial strains Bacillus spp. BZR 1159 (94.6\%) and BZR 936 (95.0\%) and a granulovirus strain of the codling moth (CpGV) BZR L-5 (100\%). Larvae of $G$. mellonella $\mathrm{L}$ were susceptible to melanization in the process of infection with new bacterial and viral agents.
\end{abstract}

\section{Introduction}

Recently, more and more attention in Russia has been paid to biological plant protection. In this regard, the search for environmentally friendly methods for regulating the number of harmful organisms is of great theoretical and practical importance. One of them is the development of microbiological preparations based on entomopathogenic microorganisms [1-2]. Bacillus thuringiensis, B. popilliae, Lysinibacillus sphaericus, Paenibacillus larva, etc.) and viruses of nuclear polyhedrosis and granulosis are actively used as active substances [3-7]. The advantage of viral and bacterial insecticides is their environmental friendliness and cumulative effect in agrocenoses [8-9]. It should be noted that viral agents have specific toxicological activity against target insects, thus having a narrowly targeted effect only on the target insect [10-13].

The use of chemical insecticides, in addition to the destruction of harmful insects, is known to inevitably reduce the number of useful entomofauna, which leads to a violation of the ecological balance of agrocenoses. In addition, with the intensive use of chemical pesticides, phytophages have a risk of developing resistance [14, 15]. Bioinsecticides solve this problem by acting selectively and destroying a certain range of pests while maintaining

\footnotetext{
* Corresponding author: 23612361@inbox.ru
} 
natural balance. However, the range of biological insecticides existing today is rather narrow in comparison with chemical ones and requires expansion [16]. In this regard, the purpose of our research was to study the insecticidal properties of entomopathogenic bacteria and viruses, which in the future may become the basis of biopreparations against agricultural pests.

\section{Materials and methods}

The objects of research are aboriginal, first isolated from farming ecosystem of southern Russia, entomopathogenic strains of bacteria and viruses from the bioresource collection (BRC) of the Federal State Budgetary Scientific Institution "Federal Research Center of Biological Plant Protection" (FSBSI FRCBPP) "State collection of entomoacariphages and microorganisms."

The bacterial strains Bacillus spp. BZR G2, BZR 936, BZR 1159 were selected for their ability to synthesize a complex of hydrolytic enzymes (lipase, chitinase, and protease) and was assessed by the insecticidal activity in vivo. The granulovirus strains of the codling moth Cydia pomonella L. (CpGV) BZR 6, BZR 10, BZR L-5, BZR L-7 were selected according to the results of the previously conducted primary screening for the large wax moth [17].

Caterpillars of the laboratory population of the large wax moth Galleria mellonella L., grown in the laboratory of chemical communication and mass breeding of insects of the FSBSI FRCBPP, were used as a test object for studying the effectiveness of bacterial and viral cultures of microorganisms. Due to its physiological characteristics, it is mass-reared for scientific and practical purposes as a model object for research in terms of assessing the effectiveness of biopreparations, as well as a food base for predatory bugs, tachin flies, trichograms, etc. [18, 19].

Bacterial strains were plated in Petri dishes (PD) by streaking on meat-peptone agar (MPA). The cultivation was carried out in a thermostat at a temperature of $+28^{\circ} \mathrm{C}$ for 48 $h$. At the end of the cultivation, an aqueous suspension was obtained by the washout method, and the number of bacterial cells was determined by the deep method [21].

Aqueous suspensions of viruses were prepared from the affected caterpillars of the codling moth, pre-selected due to the presence of obvious signs of viroses (inactivity, lethargy, discoloration of the cuticle, softening or partial necrosis of tissues). The insects were placed in test tubes with $10 \mathrm{ml}$ of sterile water per sample and left under room conditions for decomposition and natural release of the virus from the cells. Then the sample was crushed with a glass rod, filtered, and then used as a material for infection [22, 23]. To determine the titer of viral granules in the samples, the suspension was centrifuged on a $70 \%$ glycerol pad - $30 \mathrm{~min}$., $8000 \mathrm{rpm}$. [23]. Then the samples were applied to a glass slide, fixed in a burner flame, and stained by Shvetsova method [24]. A Goryaev chamber was used to count the number of granules.

G. mellonella L. was bred in a thermostat at a temperature of $25-27^{\circ} \mathrm{C}$, a relative humidity of $60-80 \%$. Caterpillars were fed with a modified artificial nutrient medium [20]. Caterpillars of the 3-5 age were used for the laboratory tests.

Testing the entomopathogenic activity of bacterial strains in vitro was carried out according to the guidelines by Burov [25]. Caterpillars of large wax moth actively moving and showing no signs of disease. Healthy, actively moving individuals were selected for the experiment. In one repetition, 50 caterpillars and $25 \mathrm{~g}$ of diet were used, treated with $25 \mathrm{ml}$ of the solution, which varied depending on the variant: in the control variant - water, in the experimental variants - suspensions of strains. The biopreparation Fermovirin YAP, SP (CpGV) and the biopreparation Lepidocide, SP (B. thuringiensis var. kurstaki, spore-crystal complex) were used as biological reference preparation. The experience is repeated three 
times. During the test, the insects were incubated at a temperature of $+25-27^{\circ} \mathrm{C}$ and a relative humidity of $60-80 \%$.

The calculation of the biological efficacy was carried out according to the Henderson and Tilton formula [9], which takes into account the changes in the number in the experimental and control variants:

$$
\mathrm{E}=100 \times(1-\mathrm{OaKb} / \mathrm{ObKa})
$$

where $\mathrm{E}$ - efficiency expressed as percentage of pest reduction adjusted for control; $\mathrm{Ob}$ - the number of live individuals before the treatment in the experiment; Oa - the number of live individuals after the treatment in the experiment; $\mathrm{Kb}$ - the number of live individuals in the control in the preliminary count; $\mathrm{Ka}$ - number of live individuals in control in subsequent counts.

Melanization of insects was assessed visually, by examining the hypodermis on the $1^{\text {st }}$ $5^{\text {th }}$ days.

\section{Results and discussion}

The minimum insecticidal effect was observed in the Bacillus sp. BZR G2 strain on the $3^{\text {st }}$ $5^{\text {th }}$ days. Strains Bacillus spp. BZR 1159 and BZR 936 showed the maximum biological efficacy on the $5^{\text {th }}$ day: 94.6 and $95.0 \%$, respectively (Table 1 ).

Table 1. Insecticidal activity and titer of aqueous suspensions of bacterial strains against larvae of the large wax moth G. mellonella L.

\begin{tabular}{|c|c|c|c|}
\hline \multirow{2}{*}{ Option } & \multirow{2}{*}{ Titre, CFU / ml } & \multicolumn{2}{|c|}{ Biological efficacy, \% } \\
\cline { 3 - 4 } & & $3^{\text {rd }}$ day & $5^{\text {th }}$ day \\
\hline Bacillus sp. BZR G2 & $(2.9 \pm 0.3) \times 10^{7}$ & 4.0 & 6.1 \\
\hline Bacillus sp. BZR 936 & $(2.2 \pm 0.1) \times 10^{8}$ & 89.3 & 94.6 \\
\hline Bacillus sp. BZR 1159 & $(6.0 \pm 0.1) \times 10^{9}$ & 93.3 & 95.0 \\
\hline $\begin{array}{c}\text { Lepidocide, SP (B. thuringiensis var. } \\
\text { kurstaki, spore-crystal complex) }\end{array}$ & $(1.9 \pm 0.1) \times 10^{9}$ & 70.0 & 87.5 \\
\hline
\end{tabular}

Thus, the insecticidal activity of new bacterial strains against the large wax moth $G$. mellonella L was confirmed.

Also, to assess the effect of bacterial insecticidal agents, signs of caterpillar melanization were evaluated in comparison with controls. Figure 1 shows the phased of the skin melanization comparing to the control individuals (no melanism, normal color).

In the control (Fig. 1-a), the hypodermis of the larva is of a typical cream color, caterpillars ranging in size from 2 to $2.5 \mathrm{~cm}$. Melanization of the affected caterpillars began with characteristic black spots on cream-colored larvae (Figure 1-b). All dead caterpillars were melanized (black larvae, Figure 1-d). 


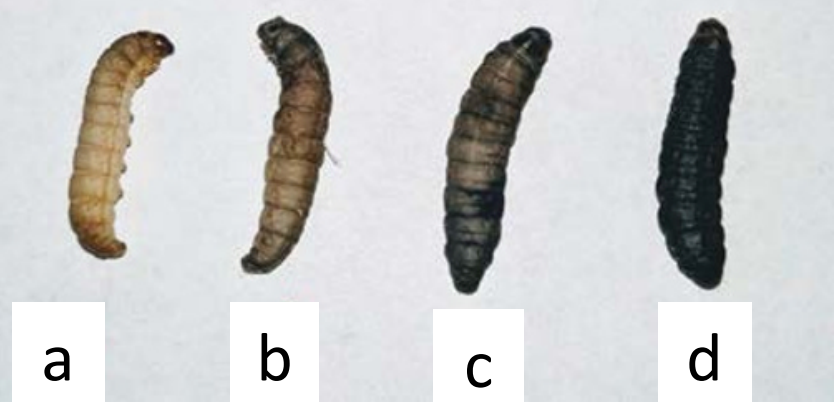

Fig. 1. Signs of melanization on G. mellonella L. (orig.) larvae a - control; b-d - different stages of melanization when infected with Bacillus sp. BZR 1159 strain

In the course of the research, the sensitivity of the laboratory population of the large wax moth G. mellonella L. to new viral strains was assessed. The test results are presented in Table 2.

Table 2. Insecticidal activity and titer of aqueous suspensions granulovirus of the codling moth $(\mathrm{CpGV})$ strains and a commercial viral preparation against larvae of the large wax moth $G$. mellonella L.

\begin{tabular}{|c|c|c|c|}
\hline \multirow{2}{*}{ Option } & \multirow{2}{*}{ Titre, granules $/ \mathrm{ml}$} & \multicolumn{2}{|c|}{ Biological efficacy, \% } \\
\cline { 3 - 4 } & & $3^{\text {rd }}$ day & $5^{\text {th }}$ day \\
\hline CpGV BZR 6 & $(3.7 \pm 0.1) \times 10^{6}$ & 2.0 & 20.0 \\
\hline CpGV BZR 10 & $(3.6 \pm 0.3) \times 10^{6}$ & 27.0 & 60.0 \\
\hline CpGV BZR L-5 & $(7.7 \pm 0.4) \times 10^{6}$ & 87.0 & 100.0 \\
\hline CpGV BZR L-7 & $(2.6 \pm 0.2) \times 10^{6}$ & 52.0 & 58.0 \\
\hline $\begin{array}{c}\text { Fermovirin YAP, SP } \\
(\text { CpGV) }\end{array}$ & $(2.0 \pm 1.0) \times 10^{9}$ & 0 & 11.0 \\
\hline
\end{tabular}

As a result of assessing the pathogenicity of new viral strains, it was found that the maximum biological efficacy was observed in CpGV BZR L-5 strain and on the $5^{\text {th }}$ day it was $100 \%$. In other strains, insecticidal activity was lower. Minimal biological efficacy was observed in the variant treated with Fermovirin YAP, SP. Thus, the results of the experiment proved the insecticidal activity of new strains of viruses against the large wax moth G. mellonella L.

Melanization was also observed when exposed to viral strains and similar to the symptoms manifested during infection with bacteria. However, most insects were not completely melanized, most of them showed spots on the surface of the hypodermis, as in the case of infection with bacterial strains in the early stages. There was no significant visual difference between the studied strains and the reference preparation. Control insects remained the typical cream color throughout the research.

Thus, as a result of a series of experiments, it was revealed that the large wax moth $G$. mellonella L. is susceptible to new bacterial and viral strains with insecticidal activity, which in the future may become the basis of biopreparation against agricultural pests. 
The studies were carried out within the framework of the Russian Foundation for Basic Research and Administration of Krasnodar region No. 19-416-233037 "Investigation of insecticidal and stress properties of new bacterial strains and entomopathogenic viruses for biological control of codling moth in cenosis in the south Russia". In our research we used Unique Scientific Facility «New generation technological line for developing microbiological plant protection products» of AllRussian Research Institute of Biological Plant Protection, Krasnodar, Russia (http://ckp-rf.ru/ № 671367).

\section{References}

1. Belova K. V., Feoktistova N. A., Zolotukhin S. N., Lydina M. A., Vasiliev D. A. Methods of isolation and biological properties of Bacillus coagulans phages. Materials of the IV International Scientific Conference dedicated to the 55th anniversary of the graduate School of the Federal State Budgetary Institution "ARRIAH". December 6. P. 22-28. (2016)

2. Yarovoy G. I., Kuzmenko V. I. Biological and economic efficiency of the use of biological preparations and growth regulators in the fight against tomato diseases. Vegetable crops of Russia. 1. P. 92-96. (2017) doi: 10.18619/2072-9146-2017-1-9296

3. Shulga I. S., Zhelyabovskaya D. A., Ostyakova, M. E., Lavrushina L. A., Gorbacheva I. E. Experimental drug "Antigallerin" against bee fireworm. Tendentsii razvitiya nauki i obrazovaniya. Razdel VIII. Veterinariya. P. 50-53. (2018) doi:10.18411/lj-3103-2018-34

4. Ben Khedher, S., Jaoua, S., \& Zouari, N. Application of statistical experimental design for optimisation of bioinsecticides production by sporeless Bacillus thuringiensis strain on cheap medium. Brazilian Journal of Microbiology. 44(3). P. 927-933. (2013) doi:10.1590/s1517-83822013000300043

5. Nugmanova T. A. The use of biological preparations for plants for the production of environmentally friendly food products. Collection of scientific papers «Netraditsionnyye prirodnyye resursy, innovatsionnyye tekhnologii i produkty». P. 103-107. (2016)

6. Shulga I. S., Zhelyabovskaya D. A., Lavrushina L. A., Gorbacheva I. E. Changes in the insecticidal activity of etomopathogenic strains of Bacillus thuringiensis during long-term storage. The Bulletin of KrasGAU. 9. C. P. 45-49. (2019)

7. Makarov Yu. A., Gorkovenko N.E., Serebryakova V. A. Screening of Bacillus pathogenic cultures for wax moth larvae. Bolezni zhivotnykh i pchel na Dal'nem Vostoke, lecheniye i profilaktika. 14. P. 45-49. (2008)

8. Sun, X. History and Current Status of Development and Use of Viral Insecticides in China. Viruses. 7(1). P. 306-319. (2015) doi:10.3390/v7010306

9. Dolzhenko T. V. Biologization and ecological optimization of the assortment of means of protection of agricultural crops from pests: Doctor of Biological Sciences thesis / Dolzhenko, Tatyana Vasilyevna. SPb., Pushkin. 301 p. (2017)

10. Dolzhenko T. V., Dolzhenko V. I. Insecticides based on entomopathogenic viruses. Agrohimiya. 4. C. 26-33. (2017)

11. Avdeenko I. A., Sochinskaya O. N. Bioinsecticides in agriculture. Scientificmethodological electronic journal "Koncept”. 11. C. 896-900. (2016)

12. Gómez Valderrama, J. A., Barrera, G., López-Ferber, M., Belaich, M., Ghiringhelli, P. D., \& Villamizar, L. Potential of betabaculoviruses to control the tomato leafminer Tuta absoluta (Meyrick). Journal of Applied Entomologyю. 142(1-2). P. 67-77. (2017) doi:10.1111/jen.12406

13. Druchinina A.V., Okhlopkova O. V. Preparation based on baculoviruses for ensuring the environmental safety of raw materials of plant origin used for food for agricultural 
animals. Proceedings of the scientific and practical conference of teachers, postgraduates, undergraduates and students of the Faculty of Veterinary Medicine of the Novosibirsk State Agrarian University. «Voprosy veterinarnoy nauki i praktiki». P. 29-31. (2019)

14. Van Leeuwen T., Dermauw W., Mavridis K. et al. Significance and interpretation of molecular diagnostics for insecticide resistance management of agricultural pests. Current Opinion in Insect Science. 39. P. 69-76. (2020) doi: 10.1016/j.cois.2020.03.006

15. Pathak M., Fareed M., Srivastava A. et al. Seasonal variations in cholinesterase activity, nerve conduction velocity and lung function among sprayers exposed to mixture of pesticides. Environmental Science and Pollution Research. 10(20). P. 7296-7300. (2013) doi: 10.1007/s11356-013-1743-5

16. State catalog of pesticides and agrochemicals approved for use in the territory of the Russian Federation. Part I. Pesticides. Ministry of Agriculture of the Russian Federation. Ministry of Agriculture of the Russian Federation. 795 p. (2021)

17. Tsygichko A. A., Asaturova A.M., Pushnya M. V., Snesareva E. G., Rodionova E. Yu. Screening of promising strains of the apple moth granulosa virus. Materials of the IV International scientific and practical conference «Sovremennoye sostoyaniye, problemy i perspektivy razvitiya agrarnoy nauki». Yalta, September 09-13. C. 292293. (2019) doi: 10.33952/09.09.2019.146

18. Osokina A. S., Kolbina L. M., Nepeyvoda S. N. Maintenance and cultivation of Galleria mellonella in laboratory conditions. Scientific notes of the Kazan State Academy of Veterinary Medicine named after N. E. Bauman.. 3(223). C. 138-142. (2015)

19. Agasyeva I. S., Ismailov V. Ya., Kiel V. I., Fedorenko E. V., Besedina E. N., Kuvika T. O., Nefedova M. V. Study of biological features of populations of the ectoparasite Habrobracon hebetor say (Hymenoptera, Braconidae) for biological plant protection. Materials of the 9th International scientific and Practical Conference «Biologicheskaya zashchita rasteniy - osnova stabilizatsii agroekosistem». Krasnodar. September 20-22. P. 106-111. (2016)

20. Ismailov V. Ya., Shirinyan Zh. A., Kvasenkov O. I. Patent. RU2214090C2. Method for obtaining wax moth - Galleria mellonella L - as host-substitute for raising entomophages. Application filed by Federal State Budgetary Scientific Institution "Federal Research Institute for Biological Plant Protection". (2003)

21. Netrusov A. I., Egorova M. A., Zakharchuk L. M. Practicum on Microbiology M.: Publishing Center "Academy". 608 p. (2005)

22. Bakhvalov S. A. Virozy insects. Insect pathogens: structural and functional aspects / ed. by V. V. Glupov. M. 736 p. (2001)

23. Kolosov A.V. Development and testing of viral entomopathogenic preparations for plant protection: dissertation of the candidate of biological sciences / Kolosov, Alexey Vladimirovich. Koltsevo. 131 p. (2011)

24. Mitrofanov V. B., Smirnov O. V. Entomopathogenic viruses in plant protection. Production of environmentally safe crop production / ed. by M. S. Sokolov, E. P. Ugryumov. P. 43-47. (1998)

25. Burov V. N., Tyuterev S. L., Sukhoruchenko G. I., Petrova T. M. Methods for assessing the environmental safety of pesticides when using them in integrated plant protection. Methodological guidelines. SPb.14 p. (1995) 